\title{
Simultaneous quantification of empagliflozin, linagliptin and metformin hydrochloride in bulk and synthetic mixture by RP-LC method
}

Ishita M. Patel ${ }^{1}$, Usmangani K. Chhalotiya ${ }^{1 *} \mathbb{0}$, Harsha D. Jani ${ }^{1}$, Devansh Kansara' ${ }^{1}$, Hetaben M. Kachhiya ${ }^{1}$ and Dimal A. Shah²

\begin{abstract}
Background: Extensive literature review revealed that no RP-LC method has been developed for simultaneous estimation of EMPA, LINA and MET in combined dosage form. This is a newer combination approved by USFDA on 4th June 2019 and it is launch in the United State Market on 27th January 2020.

Result: A simple, sensitive, specific, precise and accurate reverse phase-high performance liquid chromatography (RP- HPLC) method has been developed for simultaneous estimation of Empagliflozin, Linagliptin and Metformin $\mathrm{HCl}$ in bulk and synthetic mixture. Phenomenex $\mathrm{C}_{18}$ column $(250 \mathrm{~mm} \times 4.6 \mathrm{~mm}, 5 \mu \mathrm{m})$ was used as stationary phase for chromatographic separation through isocratic elution using Acetonitrile: Methanol: Water in a ratio (27: 20:53, $\mathrm{v} / \mathrm{v} / \mathrm{v}) \mathrm{pH} 4$ adjusted with $1 \%$ Ortho-phosphoric acid as mobile phase at flow rate $1 \mathrm{ml} / \mathrm{min}$. PDA detector was used for simultaneous analysis of all three drugs at common wavelength $223 \mathrm{~nm}$ and the each injection volume was $20 \mu \mathrm{l}$. The linearity range for Empagliflozin, Linagliptin and Metformin $\mathrm{HCl}$ was found to be $0.5-5 \mu \mathrm{g} / \mathrm{ml}, 0.25-2.5 \mu \mathrm{g} / \mathrm{ml}$, and $50-500 \mu \mathrm{g} / \mathrm{ml}$, respectively. The retention time for Empagliflozin, Linagliptin and Metformin $\mathrm{HCl}$ was found to be $14.5 \mathrm{~min}, 3.4 \mathrm{~min}$ and $2.01 \mathrm{~min}$, respectively. The percentage (\%) recovery was found to be $99.98-100.81 \%$ for Empagliflozin, 99.33-100.57\% for Linagliptin and 100.65-101.35\% for Metformin HCl respectively.
\end{abstract}

Conclusion: As per the international Conference on Harmonisation (ICH) Q2 (R1) guideline, proposed RP-LC method validation has been carried out. The proposed RP-LC method was repeatable and selective as per statistical analysis and it can be use for simultaneous estimation of Empagliflozin, Linagliptin and Metformin $\mathrm{HCl}$ in bulk and synthetic mixture. The proposed method might be applied for simultaneous estimation of all three drugs in pharmaceutical formulation.

Keywords: Empagliflozin (EMPA), Linagliptin (LINA), Metformin HCl (MET), Validation, RP-HPLC

*Correspondence: usmangani84@gmail.com

${ }^{1}$ Department of Pharmaceutical Chemistry and Analysis, Indukaka Ipcowala College of Pharmacy, Beyond GIDC, P.B. No. 53, Vitthal Udhyognagar, Gujarat 388 121, India

Full list of author information is available at the end of the article

\section{Background}

Empagliflozin (EMPA) is used as a sodium glucose cotransporter-2 (SGLT-2) inhibitor to improve glycemic control in adult patients with type 2 diabetes. SGLT-2 co-transporters reabsorb glucose from the glomerular filtrate in kidney and the glucuretic action resulting from inhibition of SGLT-2 which reduces renal absorption and lowers down the renal threshold for glucose, therefore 
increases glucose excretion which reduces hyperglycaemia and also helps in blood pressure reduction [1, 2]. Chemically EMPA is 1-chloro-4-(glucopyranos-1-yl)-2(4-(tetrahydrofuran-3-yloxy)benzyl)benzene and having empirical formula is $\mathrm{C}_{23} \mathrm{H}_{27} \mathrm{ClO}_{7}$ with molecular weight $450.91 \mathrm{~g} / \mathrm{mole}$ (Fig. 1A).

Linagliptin (LINA) is having competitive, reversible DPP-4 inhibitory action which is responsible for DPP-4 breakdown reduction of GLP-1 and glucose-dependant insulinotropic polypeptide (GIP). From beta cells of the pancreas, GLP-1 and GIP stimulate the release of insulin during inhibiting release of glucagon from pancreatic beta cells. These effects together reduce the breakdown of glycogen in the liver and increase insulin release in response to glucose [2-4]. Chemically LINA is (R)-8-(3-aminopiperidin-1-yl)-7-but-2-ynyl-3-methyl1-(4-methylquinazolin-2-ylmethyl)-3,7-dihydro-purine2,6-dione and having empirical formula is $\mathrm{C}_{25} \mathrm{H}_{28} \mathrm{~N}_{8} \mathrm{O}_{2}$ with molecular weight $472.5422 \mathrm{~g} /$ mole (Fig. 1B).

$\mathrm{N}$-dimethylmethanimidamide hydrochloride is Metformin Hydrochloride (MET). Metformin is belongs to antihyperglycemic agent of the biguanide class which is used for the management of type II diabetes. MET is having empirical formula $\mathrm{C}_{4} \mathrm{H}_{11} \mathrm{~N}_{5} . \mathrm{HCl}$ with molecular weight $165.625 \mathrm{~g} / \mathrm{mole}$ (Fig. 1C).

Metformin $\mathrm{HCl}$ is drug of choice for type II diabetes patient which lowers blood glucose concentrations in type II diabetes without causing hypoglycemia. It is also known as an insulin sensitizer which leads to decrease in insulin resistance which leads to significant reduction of plasma fasting insulin level [5].

On 4th June 2019, USFDA is approved a newer combination and is launch in the United State Market on $27^{\text {th }}$ January 2020 . Combination works by three complementary mechanisms which help in managing blood glucose in adult with type 2 diabetes [6].

A far-reaching literature survey carried out for quantitative analysis of EMPA, LINA and MET revealed that the attempts have been made to develop liquid chromatographic methods for the estimation of EMPA, LINA and MET alone and combination with other drugs [7-11, 11-14] which represent that no RP-LC method has been reported in literature review for simultaneous estimation of EMPA, LINA and MET in combined dosage form. LC methods are preferred method of analysis due to their accuracy, precision and sensitivity of instrument. RPLC method is more advantageous over HTPLC which is require a small sample size which can be modified on depending on level of quantitation needed and gives reliable results. Therefore, attempt has been made for the simultaneous estimation of EMPA, LINA and MET in synthetic mixture by RP-LC method.

\section{Methods}

\section{Instruments}

HPLC system consisted of binary pump (Model Waters 515 HPLC pump), rheodyne loop injector and PDA detector (Waters 2998). Empower- version 2 software is used for data collection and analysis. Phenomenex $\mathrm{C}_{18}$ column ( $250 \mathrm{~mm} \times 4.6 \mathrm{~mm}, 5 \mu \mathrm{m})$ is used for separation through isocratic elution using Acetonitrile: Methanol: Water in a ratio (27: 20:53, v/v/v) pH 4 adjusted with $1 \%$ Ortho-phosphoric acid as mobile phase at flow rate $1 \mathrm{ml} / \mathrm{min}$. The photo diode array (PDA) detector is used for detection monitoring at common wavelength $223 \mathrm{~nm}$ and the each injection volume was $20 \mu \mathrm{l}$. The calibrated Sartorius CP124S (Sartorius Corporation, United State) instrument is used for weighing of all the active<smiles>OC[C@H]1O[C@@H](c2ccc(Cl)c(Cc3ccc(OC4CCOC4)cc3)c2)[C@H](O)[C@@H](O)[C@@H]1O</smiles>

(A)

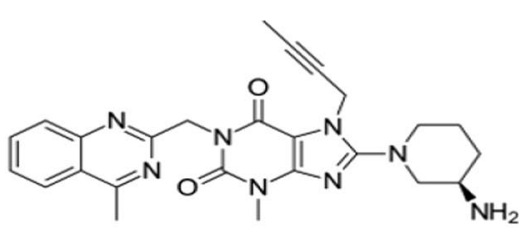

(B)<smiles>CN(C)C(=N)NC(=N)N</smiles>

(C)

Fig. 1 Chemical structure of (A) Empagliflozin. (B) Linagliptin. (C) Metformin $\mathrm{HCl}$ 
pharmaceutical ingredients, excipients and chemicals which is having weighing sensitivity $0.01 \mathrm{mg}$.

\section{Chemicals and reagents}

Analytically pure active pharmaceutical ingredients EMPA (99.23\%), LINA (98.92\%), and MET (99.12\%) was procured as a gratis samples from Torrent Pharmaceutical Pvt. Ltd., Ahmedabad, Gujarat, India, Zydus Cadila Healthcare Ltd., Ahmedabad, Gujarat, India and Sun Pharmaceutical Pvt. Ltd., Vadodara, Gujarat, India respectively. Methanol (HPLC grade) and acetonitrile (HPLC grade) were obtained from SRL Pvt. Ltd. Mumbai, India, HPLC grade water-Milli Q integral Water purification system, Merck KGaA, Darmstadt, Germany, and Ortho-phosphoric acid (AR grade) obtained from SRL Pvt. Ltd. Mumbai, India.

\section{Chromatographic system Preparation of mobile phase}

By taking premix Acetonitrile: Methanol: Water (27:20:53, v/v/v) pH 4.0 adjusted with $0.6 \mathrm{ml}$ of $1 \% \mathrm{O}-$ phosphoric acid in $200 \mathrm{ml}$ reservoir was used as a mobile phase. For degassing the mobile phase prior to use, the reservoir was sonicated for $20 \mathrm{~min}$ and mixtures of solvent were used as mobile phase.

\section{Preparation of standard stock solution}

Precisely weigh $100 \mathrm{mg}$ of MET, $2.5 \mathrm{mg}$ of LINA and $5 \mathrm{mg}$ of EMPA and transfer into the three different $10 \mathrm{ml}$ volumetric flask containing $2.0 \mathrm{ml}$ of methanol and the volume was made upto the mark with methanol which gives the stock solution having concentrations $10000 \mu \mathrm{g} /$ $\mathrm{ml}$ of MET, $250 \mu \mathrm{g} / \mathrm{ml}$ of LINA and $500 \mu \mathrm{g} / \mathrm{ml}$ of EMPA, respectively. Pipette out the $2.5 \mathrm{ml}$ of MET, $0.5 \mathrm{ml}$ of LINA and $0.5 \mathrm{ml}$ of EMPA from the above stock solution, transfer into volumetric flask of $50 \mathrm{ml}$ and make up the volume with methanol to acquire the concentration of working standard stock solution $500 \mu \mathrm{g} / \mathrm{ml}$ of MET, $2.5 \mu \mathrm{g} / \mathrm{ml}$ of LINA and $5 \mu \mathrm{g} / \mathrm{ml}$ of EMPA.

\section{Calibration curve}

From above working standard stock solution, pipette out appropriate volume of aliquots of MET $(500 \mu \mathrm{g} / \mathrm{ml})$, LINA $(2.5 \mu \mathrm{g} / \mathrm{ml})$ and EMPA $(5 \mu \mathrm{g} / \mathrm{ml})$ are transferred to different $10 \mathrm{ml}$ volumetric flask and volume was adjusted up to the mark with the mobile phase to give a final concentration range of 50,100,200,300, 400 and $500 \mu \mathrm{g} / \mathrm{ml}$ for MET, $0.25,0.5,1,1.5,2$ and $2.5 \mu \mathrm{g} / \mathrm{ml}$ for LINA and $0.5,1,2,3,4$ and $5 \mu \mathrm{g} / \mathrm{ml}$ for EMPA. By using the proposed chromatographic conditions, each solution was analyzed and the chromatogram was recorded. Calibration curves were constructed by plotting peak area $\mathrm{v} / \mathrm{s}$ concentration and regression equations were computed.

\section{Validation}

According to the International Conference on Harmonization (ICH) guidelines Q2 (R1) guidelines [15], validation of the proposed developed RP-LC method was carried out.

\section{Linearity}

Linearity was studied by preparing standard solution of 7 different concentrations of 50, 100, 200,300, 400 and $500 \mu \mathrm{g} / \mathrm{ml}$ for MET, $0.25,0.5,1,1.5,2$ and $2.5 \mu \mathrm{g} / \mathrm{ml}$ for LINA and $0.5,1,2,3,4$ and $5 \mu \mathrm{g} / \mathrm{ml}$ for EMPA. The chromatogram of each concentration was recorded 5 times from freshly prepared seven different concentrations for MET, LINA and EMPA. The terms of slope, intercept and correlation coefficient of MET, LINA and EMPA was used for the assessment of linearity. The calibration curves were developed by plotting concentration $\mathrm{v} / \mathrm{s}$ peak area $(n=5)$.

\section{Precision}

Precision study was designed in expressions of intra-day and inter-day precisions. Intraday and Interday precision was carried out by analyzing sample solution at three levels covering low, medium and high concentration of the calibration curve three times on the same day for intraday precision study and over a period of three different days $(\mathrm{n}=3)$ for interday precision study, 50, 200 and $500 \mu \mathrm{g} /$ $\mathrm{ml}$ for MET, $0.25,1$ and $2.5 \mu \mathrm{g} / \mathrm{ml}$ for LINA and, $0.5,2$ and $5 \mu \mathrm{g} / \mathrm{ml}$ for EMPA. The chromatogram was recorded and peak areas obtained were used to calculate mean and \% RSD values. The repeatability studies were carried out by estimating the response at $200 \mu \mathrm{g} / \mathrm{ml}$ for MET, $1.0 \mu \mathrm{g} / \mathrm{ml}$ for LINA and $2.0 \mu \mathrm{g} / \mathrm{ml}$ for EMPA 6 times and \% RSD of area are reported.

\section{Accuracy}

The accuracy study was performed by calculating recovery of MET, LINA and EMPA with the help of standard addition method. Known amount of MET, LINA and EMPA at 80,100 , and $120 \%$ levels were spiked to pre quantified sample solution and the amount of MET, LINA and EMPA were estimated by putting the value of peak area to the regression equation of calibration curve.

\section{Limit of detection and limit of quantification}

The limit of detection (LOD) is defined as the lowest concentration of an analyte that can detect. The limit of quantification (LOQ) is the lowest amount of analyte that can be quantitatively determined with appropriate precision and accuracy. As per ICH guideline, LOD and LOQ were calculated using the following equation:

$$
\begin{aligned}
& \mathrm{LOD}=3.3 \times \sigma / \mathrm{S} \\
& \mathrm{LOQ}=10 \times \sigma / \mathrm{S}
\end{aligned}
$$




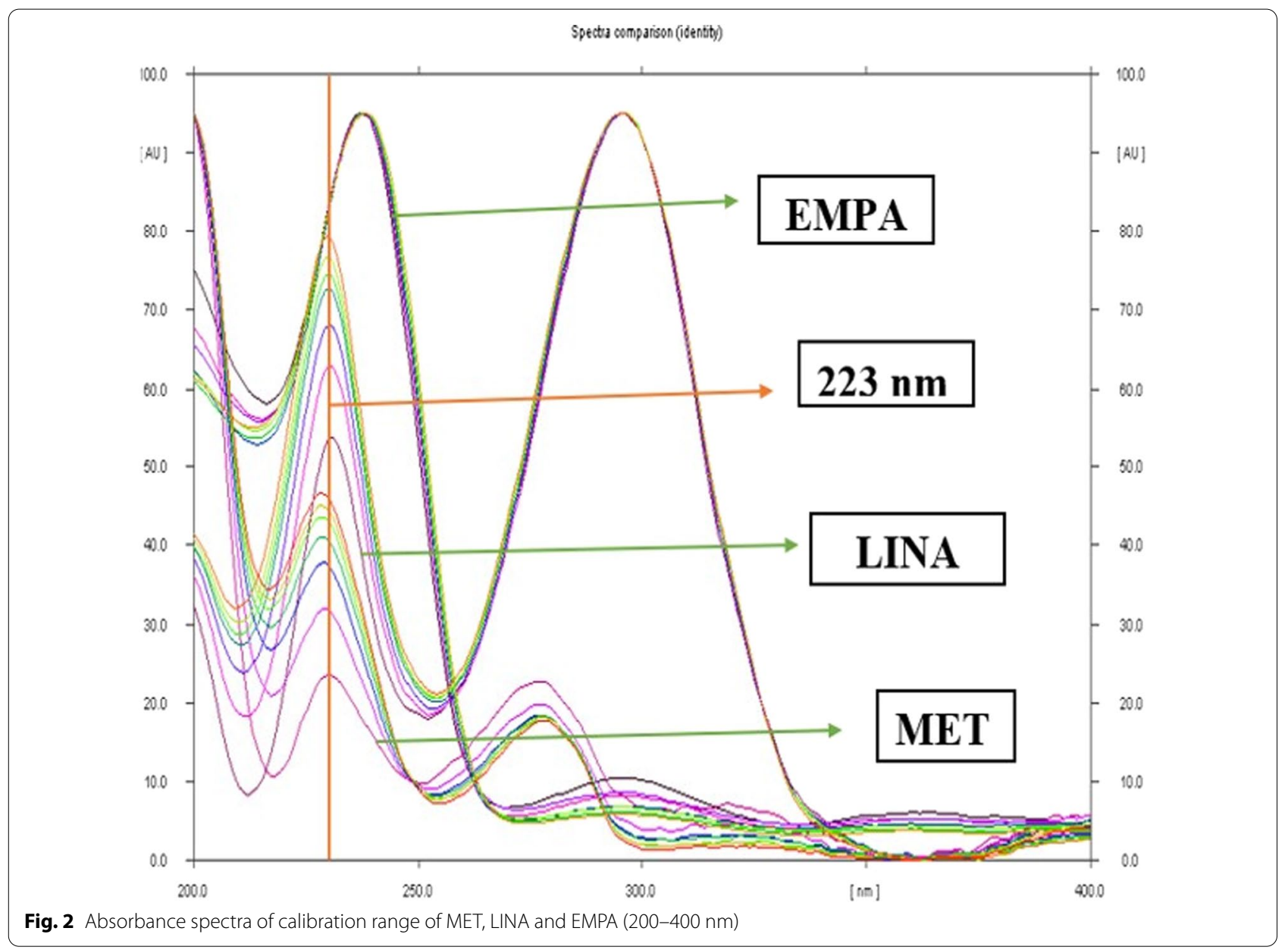

where, $\sigma$ is the standard deviation of y-intercepts of regression lines and $\mathrm{S}$ is the slope of the calibration curve.

\section{Robustness}

The robustness study has been carried out by a deliberate change in the proposed RP-LC chromatographic condition parameters like detection wavelength, flow-rate of mobile phase and the mobile phase solvent make on the results were examined for the concentration of $200 \mu \mathrm{g} /$ $\mathrm{ml}$ for MET, $1 \mu \mathrm{g} / \mathrm{ml}$ for LINA and $2 \mu \mathrm{g} / \mathrm{ml}$ for EMPA. The average and \%RSD of peak retention time were calculated.

\section{Specificity}

Specificity is the ability to assess unequivocally the analyte in the presence of components, which may be expected to be present. Typically these might be including impurities, degradants, preservatives, and excipients for checking the interference which are used in synthetic mixture. The developed method was found to be specific.

\section{System suitability}

The adequate performance of liquid chromatographic system can be assessed by System suitability parameters. A system suitability test requires ensuring that a given operating system may be normally applicable because of normal variation in equipment, supplies and techniques. System suitability also require for the verification of the resolution and reproducibility of the chromatographic system which are adequate for the analysis to be done.

\section{Analysis of synthetic mixture [16]}

The synthetic mixture of MET, LINA and EMPA was prepared in ratio of $500 \mathrm{mg}: 2.5 \mathrm{mg}: 5 \mathrm{mg}$ respectively. Common excipients like Hydroxypropyl methylcellulose $0.34 \mathrm{~g}$ [HPMC], Polyethylene glycol 0.24 g [PEG], Magnesium stearate $0.15 \mathrm{~g}$, Talc $0.18 \mathrm{~g}$ were weighed accurately and transfer into motor pestle along with $0.1 \mathrm{~g}$ of EMPA, $0.05 \mathrm{~g}$ of LINA, and $10 \mathrm{~g}$ of MET which is equivalent to 20 tablets. Synthetic mixture powder $(0.554 \mathrm{~g})$ was accurately weighed and transferred into $100 \mathrm{ml}$ volumetric flask containing $20 \mathrm{ml}$ of methanol. It was sonicated for 


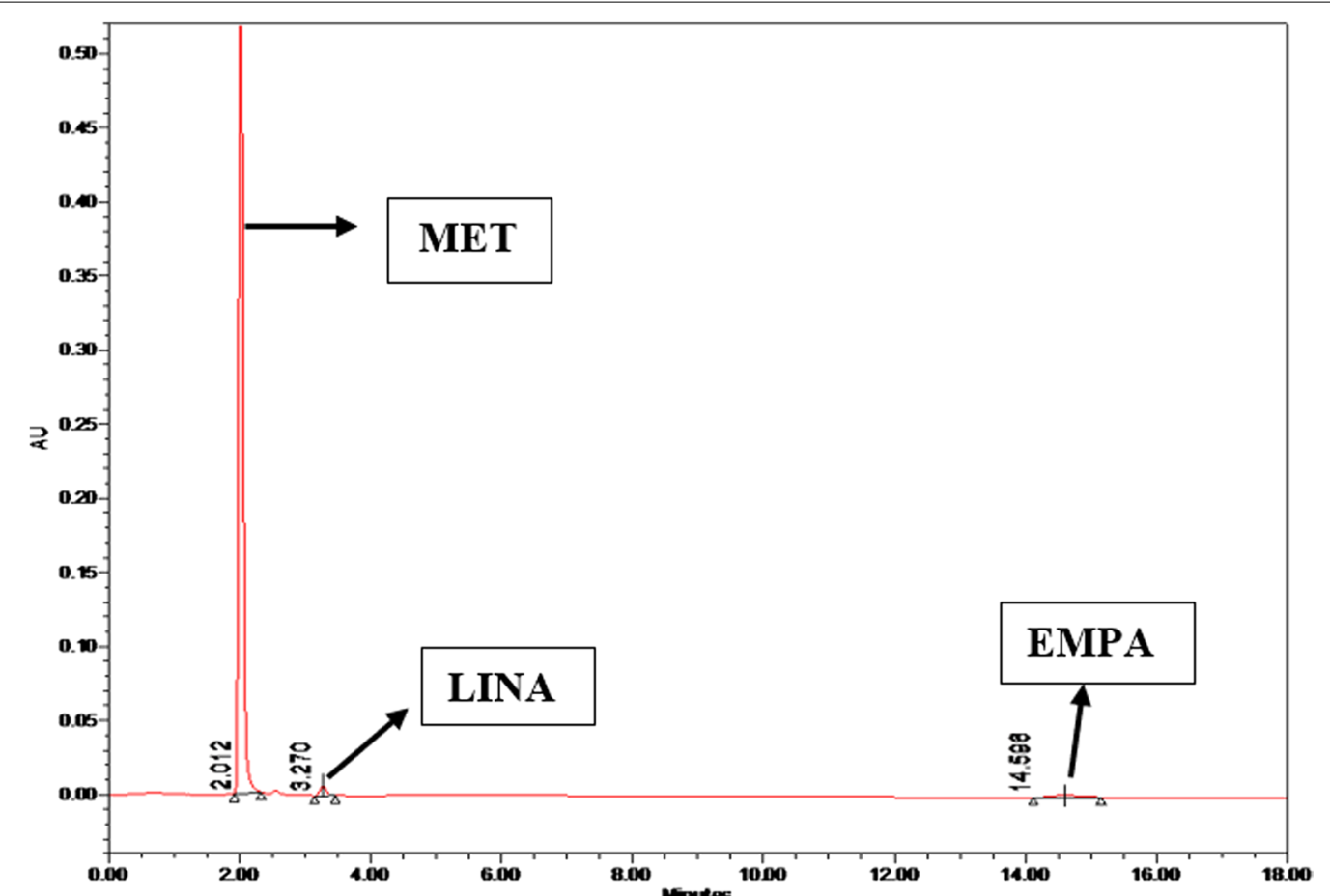

Fig. 3 Chromatogram of MET $(50 \mu \mathrm{g} / \mathrm{ml})$, LINA $(0.25 \mu \mathrm{g} / \mathrm{ml})$ and EMPA $(0.5 \mu \mathrm{g} / \mathrm{ml})$ using Acetonitrile: Methanol: Water (27: 20: $53, \mathrm{v} / \mathrm{v} / \mathrm{v}) \mathrm{pH} 4.0$ adjusted wit $1 \%$ OPA

Table 1 Regression Analysis of calibration curve

\begin{tabular}{llll}
\hline Parameter & MET & LINA & EMPA \\
\hline Range $(\mu \mathrm{g} / \mathrm{ml})$ & $50-500$ & $0.25-2.5$ & $0.5-5$ \\
Regression coefficient $\left(\mathrm{R}^{2}\right)$ & 0.9981 & 0.9967 & 0.9968 \\
$\begin{array}{l}\text { Slope of regression equation } \\
\text { Standard deviation of }\end{array}$ & $50,738.2$ & 91,942 & 43,503 \\
slope & & & \\
Intercept of regression equation & 756.03 & 1928.75 & 244.10 \\
Standard deviation of intercept & $86,870.96$ & $\mathbf{1 1 4 6 . 3 1 2}$ & 3715.22 \\
\hline
\end{tabular}

15 min and solution was filtered using Whatman filter paper No.42. Filtrate was collected in another $100 \mathrm{ml}$ volumetric flask and the residue was washed with few amount of methanol, the filtrate and residue was combined and methanol was added upto the mark. From the above solution, $0.4 \mathrm{ml}$ of aliquot was pipette out into the $10 \mathrm{ml}$ volumetric flask and methanol was added up to the mark to obtain absolute concentration of $200 \mu \mathrm{g} /$ $\mathrm{ml}$ for MET, $1.0 \mu \mathrm{g} / \mathrm{ml}$ for LINA and $2.0 \mu \mathrm{g} / \mathrm{ml}$ for EMPA respectively. The chromatogram was recorded at $223 \mathrm{~nm}$ and the quantification was carried out by keeping these values in the regression equation of calibration curve.

\section{Results}

\section{Selection of analytical wavelength}

The solution of EMPA, LINA and MET having the concentration of $10 \mu \mathrm{g} / \mathrm{ml}$ was scanned in the range of 200 $400 \mathrm{~nm}$, all three drug shows considerable absorbance at common wavelength $223 \mathrm{~nm}$. Therefore $223 \mathrm{~nm}$ was a choice of an analytical wavelength for the analysis of all three drugs. The overlay spectra for selection of analytical wavelength are shown in Fig. 2.

\section{Optimization of mobile phase}

Several combinations of solvents were tried for optimization of mobile phase like Methanol: Water (80:20, v/v), Acetonitrile: Water $(60: 40, \mathrm{v} / \mathrm{v})$, Acetonitrile: Methanol (50:50, v/v) and Acetonitrile: Methanol: Water (20:25:50, $\mathrm{v} / \mathrm{v} / \mathrm{v}) \mathrm{pH} 4.0$ adjusted with $1 \%$ Ortho-phosphoric acid (OPA). The mobile phase containing Acetonitrile (ACN): Methanol: Water (27:20:53, v/v/v) pH 4 adjusted with $0.6 \mathrm{ml}$ of $1 \%$ Ortho-phosphoric acid (OPA) and showed satisfactory results at a flow rate of $1 \mathrm{ml} / \mathrm{min}$. The retention time was found to be $2.01 \mathrm{~min}$ for MET, $3.2 \mathrm{~min}$ LINA and $14.5 \mathrm{~min}$ for EMPA. Where, total run time of analysis was 18 min (Fig. 3). 


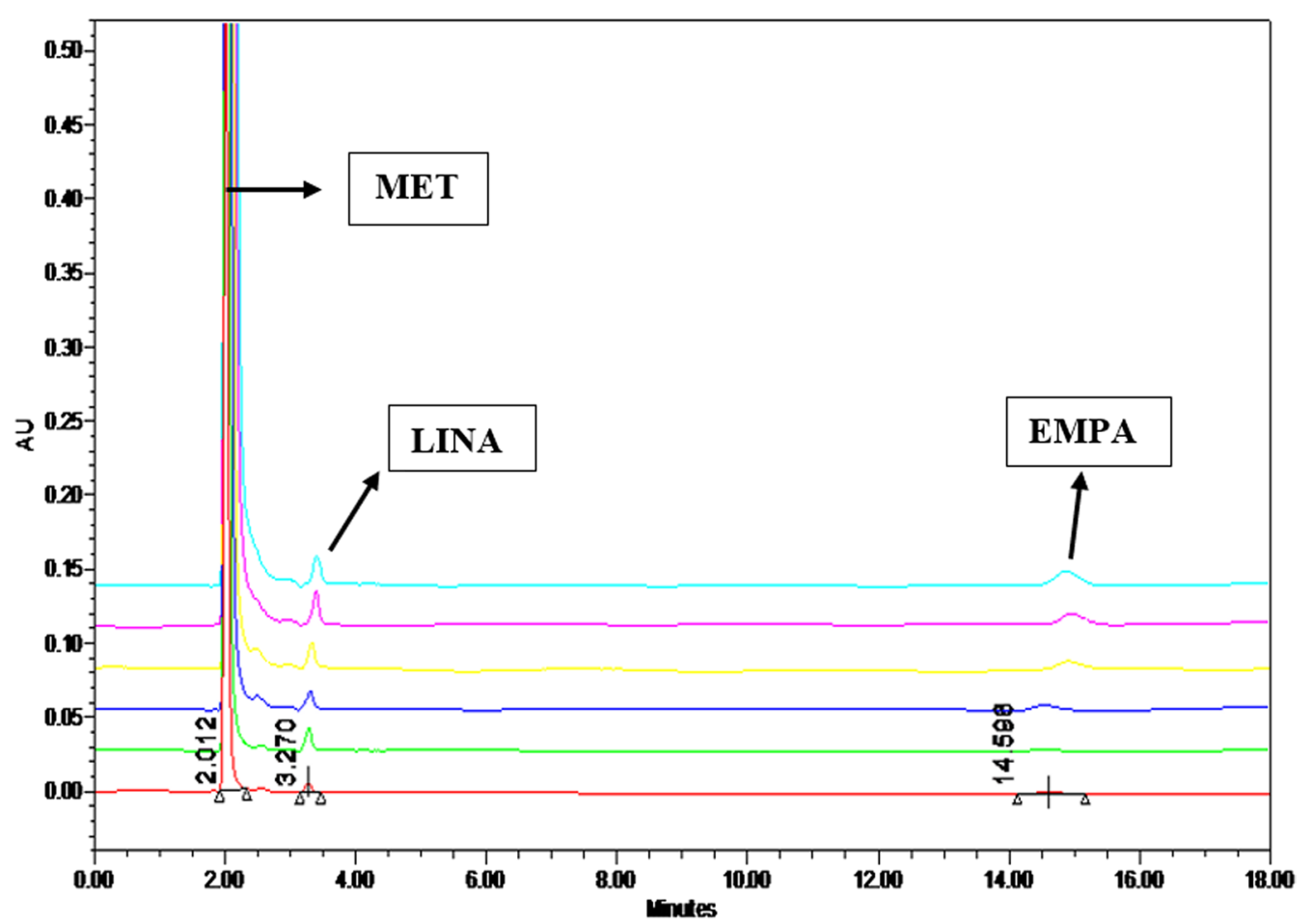

Fig. 4 Overlay Chromatogram of MET (50-500 $\mu \mathrm{g} / \mathrm{ml})$, LINA $(0.25-2.5 \mu \mathrm{g} / \mathrm{ml})$ and EMPA $(0.5-5 \mu \mathrm{g} / \mathrm{ml})$ using Acetonitrile: Methanol: Water (27: 20 : $53, \mathrm{v} / \mathrm{v} / \mathrm{v}) \mathrm{pH} 4.0$ adjusted with $1 \%$ OPA

Table 2 Summary of Validation Parameters

\begin{tabular}{|c|c|c|c|}
\hline Parameter & MET & LINA & EMPA \\
\hline Range $(\mu \mathrm{g} / \mathrm{ml})$ & $50-500$ & $0.25-2.5$ & $0.5-1$ \\
\hline Limit of detection (LOD) & 5.65 & 0.04 & 0.03 \\
\hline $\begin{array}{l}\text { Limit of quantification } \\
\quad(\mathrm{LOQ})\end{array}$ & 17.12 & 0.12 & 0.10 \\
\hline Retention time & 2.01 & 3.2 & 14.5 \\
\hline Accuracy (\%) & $100.65-101.35$ & $99.33-100.57$ & $99.98-100.81$ \\
\hline \multicolumn{4}{|l|}{ Precision (\%RSD) } \\
\hline Intraday $(n=3)$ & $0.21-1.12$ & $0.20-1.27$ & $0.29-1.69$ \\
\hline Interday $(\mathrm{n}=3)$ & $1.10-1.91$ & $0.76-1.53$ & $0.70-1.78$ \\
\hline \multicolumn{4}{|l|}{$\begin{array}{l}\text { Instrumental precision } \\
(\% \text { RSD) }\end{array}$} \\
\hline Repeatability $(n=6)$ & 1.12 & 0.97 & 0.62 \\
\hline
\end{tabular}

\section{Linearity}

The linearity study was performed by considering the clinical dose ratio of all the three drugs. The method was found to be linear in the range $50-500 \mu \mathrm{g} / \mathrm{ml}$ for MET, $0.25-2.5 \mu \mathrm{g} / \mathrm{ml}$ for LINA and $0.5-5 \mu \mathrm{g} / \mathrm{ml}$ for EMPA with the correlation coefficient $0.9981,0.9967$ and 0.9968 respectively. The data of regression analysis of calibration curve was shown in Table 1 and overlay spectra of MET (50-500 $\mu \mathrm{g} / \mathrm{ml})$, LINA $(0.25-2.5 \mu \mathrm{g} / \mathrm{ml})$ and EMPA $(0.5-5 \mu \mathrm{g} / \mathrm{ml})$ at $223 \mathrm{~nm}$ shown in (Fig. 4). The correlation coefficient values were found to be more than 0.9950 which indicate that the method is linear in relationship with respect to recorded area and concentrations.

Table 3 Accuracy studies of proposed method

\begin{tabular}{|c|c|c|c|c|c|c|c|c|c|c|c|}
\hline \multicolumn{3}{|c|}{$\begin{array}{l}\text { Amount of drug taken from } \\
\text { samples }(\mu \mathrm{g} / \mathrm{ml})\end{array}$} & \multicolumn{3}{|c|}{$\begin{array}{l}\text { Amount of standard drug } \\
\text { spiked }(\mu \mathrm{g} / \mathrm{ml})\end{array}$} & \multicolumn{3}{|c|}{$\begin{array}{l}\text { Average Amount of } \\
\text { recovered Standard }(\mu \mathrm{g} / \mathrm{ml}) \\
(\mathrm{n}=3)\end{array}$} & \multicolumn{3}{|c|}{$\%$ Recovery $\pm S D(n=3)$} \\
\hline MET & LINA & EMPA & MET & LINA & EMPA & MET & LINA & EMPA & MET & LINA & EMPA \\
\hline 200 & 1 & 2 & 160 & 0.8 & 1.6 & 161 & 0.81 & 1.58 & $100.62 \pm 0.95$ & $101.25 \pm 0.62$ & $98.75 \pm 0.80$ \\
\hline 200 & 1 & 2 & 200 & 1 & 2 & 203 & 0.98 & 2.02 & $101.50 \pm 0.72$ & $98.00 \pm 1.1$ & $101.00 \pm 0.56$ \\
\hline 200 & 1 & 2 & 240 & 1.2 & 2.4 & 237 & 1.18 & 2.38 & $98.75 \pm 0.84$ & $98.33 \pm 0.92$ & $99.17 \pm 1.12$ \\
\hline
\end{tabular}


Table 4 Robustness studies of proposed method

\begin{tabular}{|c|c|c|c|c|c|c|c|}
\hline \multirow[t]{2}{*}{$\begin{array}{l}\text { Normal } \\
\text { Condition }\end{array}$} & \multirow[t]{2}{*}{$\begin{array}{l}\text { Changed } \\
\text { condition }\end{array}$} & \multicolumn{2}{|c|}{$\begin{array}{l}\text { MET } \\
(200 \mu \mathrm{g} / \mathrm{ml}) \\
(\mathrm{n}=3)\end{array}$} & \multicolumn{2}{|l|}{$\begin{array}{l}\text { LINA } \\
(1 \mu \mathrm{g} / \mathrm{ml}) \\
(\mathrm{n}=3)\end{array}$} & \multicolumn{2}{|l|}{$\begin{array}{l}\text { EMPA } \\
(2 \mu \mathrm{g} / \mathrm{ml}) \\
(\mathrm{n}=3)\end{array}$} \\
\hline & & $\begin{array}{l}\text { Rt mean } \\
\pm \\
\text { SD }\end{array}$ & $\%$ RSD & $\begin{array}{l}\text { Rt mean } \\
\pm \\
\text { SD }\end{array}$ & $\%$ RSD & $\begin{array}{l}\text { Rt mean } \\
\pm \\
\text { SD }\end{array}$ & \%RSD \\
\hline \multirow[t]{2}{*}{$\begin{array}{l}\text { Wavelength } \\
223 \mathrm{~nm}\end{array}$} & 221 & $\begin{array}{c}2.14 \\
\pm \\
0.03\end{array}$ & 1.63 & $\begin{array}{c}3.37 \\
\pm \\
0.06\end{array}$ & 1.80 & $\begin{array}{c}14.3 \\
\pm \\
0.15\end{array}$ & 1.06 \\
\hline & 225 & $\begin{array}{c}2.08 \\
\pm \\
0.03\end{array}$ & 1.66 & $\begin{array}{c}3.36 \\
\pm \\
0.05\end{array}$ & 1.71 & $\begin{array}{r}14.3 \\
\pm \\
0.15\end{array}$ & 1.06 \\
\hline \multirow[t]{2}{*}{$\begin{array}{l}\text { Flow rate } \\
1 \mathrm{ml} / \mathrm{min}\end{array}$} & $0.9 \mathrm{ml} / \mathrm{min}$ & $\begin{array}{c}2.15 \\
\pm \\
0.03\end{array}$ & 1.67 & $\begin{array}{c}3.43 \\
\pm \\
0.05\end{array}$ & 1.51 & $\begin{array}{l}14.23 \\
\pm \\
0.12\end{array}$ & 0.8 \\
\hline & $1.1 \mathrm{ml} / \mathrm{mi}$ & $\begin{array}{c}1.80 \\
\pm \\
0.01\end{array}$ & 0.84 & $\begin{array}{c}2.87 \\
\pm \\
0.04\end{array}$ & 1.60 & $\begin{array}{c}13.04 \\
\pm \\
0.25\end{array}$ & 1.95 \\
\hline \multirow[t]{2}{*}{$\begin{array}{l}\text { Acetonitrile and Methanol } \\
\text { (HPLC Grade) } \\
\text { SRL Pvt.Ltd }\end{array}$} & $\begin{array}{l}\text { Acetonitrile and Methanol } \\
\text { (HPLC Grade) } \\
\text { E-Merck Pvt. Ltd }\end{array}$ & $\begin{array}{c}2.06 \\
\pm \\
0.03\end{array}$ & 1.55 & $\begin{array}{c}3.44 \\
\pm \\
0.06\end{array}$ & 1.74 & $\begin{array}{c}14.35 \\
\pm \\
0.21\end{array}$ & 1.47 \\
\hline & $\begin{array}{l}\text { Acetonitrile and Methanol } \\
\text { (HPLC Grade) } \\
\text { Rankem Pvt. Ltd }\end{array}$ & $\begin{array}{c}2.06 \\
\pm \\
0.04\end{array}$ & 1.94 & $\begin{array}{c}3.44 \\
\pm \\
0.05\end{array}$ & 1.70 & $\begin{array}{c}14.36 \\
\pm \\
0.15\end{array}$ & 1.06 \\
\hline
\end{tabular}

Table 5 System suitability of proposed method

\begin{tabular}{lrll}
\hline Parameter & \multicolumn{1}{c}{ MET } & LINA & EMPA \\
\hline Retention time $(\mathrm{min})$ & 2.01 & 3.4 & 14.5 \\
Capacity factor $\left(\mathrm{k}^{\prime}\right)$ & 0.82 & 2.09 & 12.18 \\
Theoretical plate $(\mathrm{N})$ & 2238.21 & 32,021 & 2426.62 \\
Tailing factor $\left(\mathrm{T}_{\mathrm{f}}\right)$ & 1.25 & 1 & 1 \\
Resolution $(\mathrm{Rs})$ & 2.52 & 22.38 & - \\
\hline
\end{tabular}

\section{Precision}

The intraday and interday variation in the method responses were studied using precision study. The intraday and inter-day precision was performed and the \%RSD of MET, LINA and EMPA was found to be $0.21-$ $1.12,0.20-1.27$ and $0.29-1.69$ for intraday and \% RSD of MET, LINA and EMPA was found to be 1.10-1.91, 0.761.53 , and $0.71-1.78$ respectively. Instrumental precision was carried out by performing injection repeatability test and the \%RSD of MET, LINA and EMPA was found to be $1.12 \%, 0.97 \%$ and $0.62 \%$. The data of intraday, interday and repeatability was shown in Table 2 . The variability in the responses was less than $2 \%$ for intra-day, inter-day and repeatability study, which indicate that the method is precise.

\section{Accuracy}

The percentage (\%) recoveries of MET, LINA and EMPA was determined by a known amount of standard was spiked into pre-analyzed sample solutions. The recoveries were found to be $100.65-101.35 \%$ for $\mathrm{MET}$, 99.33-100.57\% for LINA and 99.89-100.81\% for EMPA respectively. The accuracy data was shown in Table 3. The percentage (\%) recoveries for all three drugs were found to be in the range of 95 to $102 \%$, which indicate the method is accurate.

\section{Limit of detection and Limit of quantification}

The LOD and LOQ were carried out by signal to noise ratio. The lowest amount of drug (LOD) for MET, LINA and EMPA was found to be $5.65 \mu \mathrm{g} / \mathrm{ml}, 0.04 \mu \mathrm{g} /$ $\mathrm{ml}, 0.03 \mu \mathrm{g} / \mathrm{ml}$ and the lowest amount of quantification (LOQ) was $17.12 \mu \mathrm{g} / \mathrm{ml}, 0.12 \mu \mathrm{g} / \mathrm{ml}$ and $0.10 \mu \mathrm{g} / \mathrm{ml}$ respectively.

\section{Specificity}

The specificity study was performed to check the interference of excipients used in the preparation of synthetic mixture and there is no any interference observed by excipients at the time of elution of all three different drugs at the respective retention time. The developed method was found to be specific. 


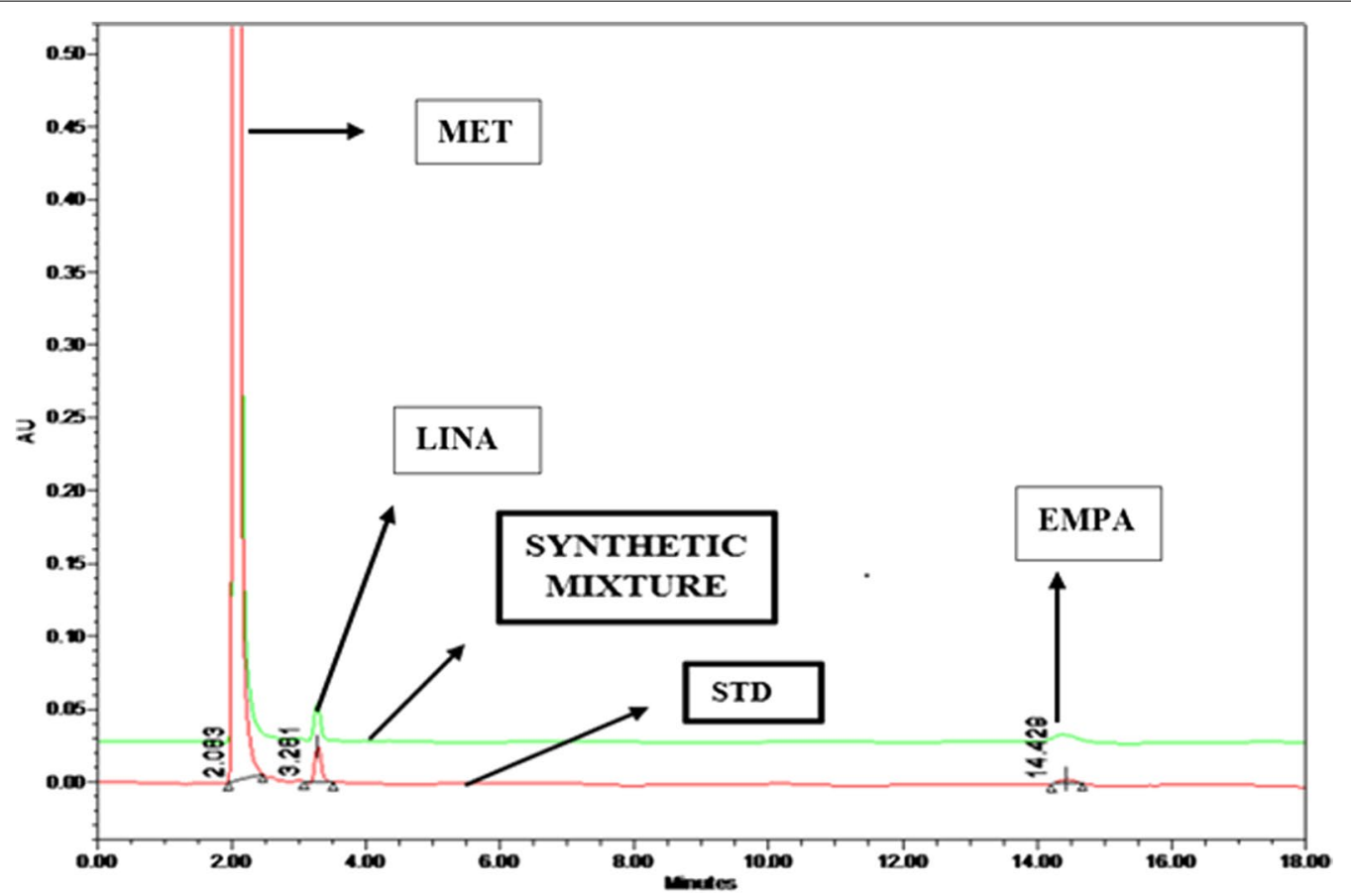

Fig. 5 Overlay Chromatogram of standard and synthetic mixture of MET ( $200 \mu \mathrm{g} / \mathrm{ml})$, LINA $(1 \mu \mathrm{g} / \mathrm{ml})$ and EMPA $(2 \mu \mathrm{g} / \mathrm{ml})$ using Acetonitrile: Methanol: Water (27: 20:53, v/v/v) pH 4.0 adjusted wit 1\% OPA

\section{Robustness}

After an introducing small and deliberate changes in chromatographic condition parameters like change in detection wavelength, flow rate, and make of mobile phase solvent, the \% RSD of retention time of all three drugs was found to be less than $2 \%$ which confirming that the proposed method is robust. The data of robustness studies is shown in Table 4 .

\section{System suitability}

The results of system suitability test are reported in Table 5.

\section{Analysis of synthetic mixture}

The proposed RP-LC method is applied for the simultaneous estimation of MET, LINA and EMPA from the prepared synthetic mixture. The \% amount of drug for MET, LINA and EMPA was found to be 100.92$101.39 \%, 98.55-100.76 \%$ and $99.33-101.22 \%$, respectively. The overlay Chromatogram of standard and prepared synthetic mixture of MET $(200 \mu \mathrm{g} / \mathrm{ml})$ LINA $(1 \mu \mathrm{g} / \mathrm{ml})$ and EMPA $(2 \mu \mathrm{g} / \mathrm{ml})$ are shown in (Fig. 5).

\section{Discussion}

The proposed RP-LC method is used for simultaneous estimation of EMPA, LINA and MET in bulk and synthetic mixture. Optimization of chromatographic conditions was achieved and with the help of Phenomenex $\mathrm{C}_{18}$ column $(250 \mathrm{~mm} \times 4.6 \mathrm{~mm}, 5 \mu \mathrm{m})$ through isocratic elution by Acetonitrile: Methanol: Water in the ratio of (27: $20: 53, \mathrm{v} / \mathrm{v} / \mathrm{v}) \mathrm{pH} 4.0$ adjusted with $1 \%$ Ortho-phosphoric acid as mobile phase at flow rate $1 \mathrm{ml} / \mathrm{min}$, the separation of all three drugs were achieved. The linearity for MET, LINA and EMPA was found to be $50-500 \mu \mathrm{g} /$ $\mathrm{ml}, 0.25-2.5 \mu \mathrm{g} / \mathrm{ml}$ and $0.5-5 \mu \mathrm{g} / \mathrm{ml}$, respectively. Table 4 is represent accuracy data and the \% recoveries for MET, LINA and EMPA were found to be 100.65-101.35\%, 99.33-100.57\% and $99.89-100.81 \%$, respectively. The specificity study was performed to check the interference of excipients used in the preparation of synthetic mixture and there is no any interference observed by excipients at the time of elution of all three different drugs which represent the method is specific. Table 5 represent the data of Robustness of the proposed developed RP-LC method is a measure of its ability to remain unaffected by small but deliberate change of the chromatographic method parameters. It was estimated by small changes in the chromatographic conditions like change in detection wavelength $( \pm 2 \mathrm{~nm})$, change in flow rate $( \pm 0.1 \mathrm{ml})$ and change in mobile phase solvent make which represents 
the minor changes does not affect on the symmetry of peak and retention time $\left(R_{t}\right)$ of MET, LINA and EMPA which confirming the reliability and robustness of the method. The percentage (\%) amount of all three drugs were found to be more than $98 \%$ in the assay of synthetic mixture which specify that the method provides accurate and precise results. As compared to reported TLC method, the proposed RP-LC method is more sensitive, accurate, robust and precise [17].

\section{Conclusions}

The proposed study describes that RP-LC method was developed and validated for the simultaneous estimation of EMPA, LINA and MET in bulk and synthetic mixture as per ICH Q2(R1) guidelines and found to be sensitive, accurate and precise. The proposed RP-LC method was repeatable and selective as per statistical analysis and the proposed method might be applied for simultaneous estimation of all three drugs in pharmaceutical formulation. As compared to reported TLC method, the proposed RP-LC method is more sensitive, accurate, robust and precise therefore $\mathrm{R}-\mathrm{LC}$ method provides more accurate results and requires less quantity of sample. Due to complete automation, HPLC is preferred over TLC method as a pharmacopoeia method of analysis. The results published HPTLC manuscript was found to be effective for qualitative analysis, however proposed RP-LC method was found to be more accurate for quantitative analysis.

\footnotetext{
Abbreviations

HPLC: High Performance liquid chromatography; RP-HPLC: Reverse Phase High Performance liquid Chromatography; EMPA: Empagliflozin; LINA: Linagliptin; MET: Metformin HCl; OPA: Ortho phosphoric acid; LOQ: Limit of Quantitation; LOD: Limit of Detection; \%RSD: Relative standard deviation; Rt: Retention time.
}

\section{Acknowledgements}

All authors are very thankful SICART, Vallabh Vidyanagar and Indukaka Ipcowala College of Pharmacy, New Vallabh Vidyanagar for providing necessary facilities to carry out research work.

\section{Authors' contributions}

All authors associated with this research work declared that there is no conflict of interest for publication of work. All authors have read and approved the manuscript. The contribution of each authors are mentioned below: IMP: $\mathrm{He}$ is post graduate student and above work has been carried out by him as dissertation work. UKC: He is a mentor of IMP and under his noble guidance proposed method has been developed and validated as per ICH guideline. He is also giving training for ease of operation sophisticated reverse phase liquid chromatography instrument and involved in interpretation of data. HDJ: She is a mentor of IMP and under her noble guidance student can understand the concept of authentication of Active Pharmaceutical Ingredients by different analytical techniques She is also involved in interpretation of data. HMK: She is a co-mentor of KP and under her noble guidance student can understand the concept of mobile phase selection and how to optimize chromatographic conditions. She is also involved in interpretation of data. DK: He is a helping hand throughout cited research work. DAS: Through his good relationship with pharmaceutical industry we have received all active pharmaceutical ingredients and he is having sound technical knowledge Waters HPLC software system. All authors read and approved the final manuscript.
}

Funding

This research did not receive any specific grant from funding agencies in the public, commercial, or not-for-profit sectors.

Availability of data and materials

All data and material are available upon request.

\section{Declarations}

Ethics approval and consent to participate

Not applicable.

\section{Consent for publication}

Not applicable.

\section{Competing interests}

No competing interests to declare.

\section{Author details}

${ }^{1}$ Department of Pharmaceutical Chemistry and Analysis, Indukaka Ipcowala College of Pharmacy, Beyond GIDC, P.B. No. 53, Vitthal Udhyognagar, Gujarat 388 121, India. ${ }^{2}$ Department of Pharmaceutical Analysis, Babaria Institute of Pharmacy, Vernama, Vadodara, Gujarat, India.

Received: 7 May 2021 Accepted: 25 August 2021

Published online: 30 August 2021

\section{References}

1. Drug bank, Empagliflozin, https://www.drugbank.ca/drugs/DB09038. Accessed 9 July 2019

2. Pubchem, Empagliflozin, https://pubchem.ncbi.nlm.nih.gov/compound/ Empagliflozin. Accessed 15 September 2019

3. Drug bank, Linagliptin, https://www.drugbank.ca/drugs/DB08882. Accessed 16 July 2019

4. Pubchem, Linagliptin, https://pubchem.ncbi.nlm.nih.gov/compound/ Linagliptin. Accessed 16 July 2019

5. Drug bank Metformin HCl, https://www.drugbank.ca/drugs/DB00331. Accessed 8 July 2019

6. Approval date for the combination, https://www.biospace.com/article/ releases/u-s-fda-accepts-new-drug-application-for-triple-combinationtablet-for-adults-with-type-2-diabetes/. Accessed 16 July 2019

7. Padmaja N, Veerabhadram G (2016) Method development and validation of RP-HPLC method for the estimation of empagliflozin in API. Int J Pharm Sci Res 7(2):724-727. https://doi.org/10.13040/IJPSR.0975-8232. 7(2).724-27

8. Madhusudhan P, Reddy MR, Devanna N (2015) RPHPLC Method Development and Validation for Simultaneous Determination of Linagliptin and Empagliflozin in Tablet Dosage Form. Int Adv Res J Sci Eng Tech 2(2):95-99. https://doi.org/10.17148/IARJSET

9. Godasu SK, Sreenivas SA (2017) A new validated RP-HPLC method for the determination of Metformin $\mathrm{HCl}$ and Empagliflozin in its bulk and Pharmaceutical dosage forms. Int J Pharm Sci Res 8(5):2223-2232. https://doi.org/10.13040/IJPSR.0975-8232.8(5).2223-32

10. Rajbangshi JC, Alam MM, Hossain MS, Islam MS, Rouf A (2018) Development and Validation of a RP-HPLC Method for Quantitative Analysis of Linagliptin in Bulk and Dosage Forms. Dhaka Uni J Pharm Sci 17(2):175-182

11. doi:https://doi.org/10.3329/dujps.v17i2.39173

12. Pandya RH, Rathod R, Maheswari DG (2014) Bioanalytical method development and validation for simultaneous determination of linagliptin and metformin drugs in human plasma by RP-HPLC method. Pharmacophore 5(2):202-218

13. Shirisha S, Haque MA, Sireesha D, Bakshi V, Harshini S (2014) Development and validation of RP-HPLC method for simultaneous estimation of metformin and linagliptin in combined pharmaceutical dosage form. Int J Pharm Res Sci 2:491-495 
14. Varaprasad C, Asif M, Ramakrishna K (2015) RP-HPLC method for simultaneous estimation of metformin and linagliptin in tablet dosage form. Rasayan J Chem 8(4):426-432.

15. Chhetri HP, Thapa P, Van Schepdael A (2014) Simple HPLC-UV method for the quantification of metformin in human plasma with one step protein precipitation. Saudi Pharm J 22(5):483-487. https://doi.org/10 1016/j.jsps.2013.12.011

16. Kar M, Choudhury PK (2009) HPLC method for estimation of metformin hydrochloride in formulated microspheres and tablet dosage form. Ind J Pharm Sci 71(3):318-320. https://doi.org/10.4103/0250-474X.56031

17. $\mathrm{ICH},(\mathrm{Q} 2 \mathrm{R} 1)$, Validation of Analytical Procedures: Text and Methodology, International Conference on Harmonization, Geneva, Switzerland, (2005).
18. Boheringer Ingelheium International GMBH. Pharmaceutical composition, Methods for treating and uses thereof. WO 2017/093419 A1, 2017

19. Patel IM, Chhalotiya UK, Jani HD, Kansara D, Shah DA (2020) Densitometric simultaneous estimation of combination of empagliflozin, linagliptin and metformin hydrochloride used in the treatment of type 2 diabetes mellitus. JPC- J Planar Chromat 33(2):109-118. https://doi.org/10.1007/ s00764-020-00026-z

\section{Publisher's Note}

Springer Nature remains neutral with regard to jurisdictional claims in published maps and institutional affiliations.

\section{Submit your manuscript to a SpringerOpen ${ }^{\circ}$ journal and benefit from:}

- Convenient online submission

- Rigorous peer review

- Open access: articles freely available online

- High visibility within the field

- Retaining the copyright to your article

Submit your next manuscript at springeropen.com 